\title{
ARAŞTIRMA / RESEARCH \\ Cerrahi ve dahiliye servislerinde çalışan hemşirelerin işe bağlı gerginlik ve iş doyumu düzeylerinin değerlendirilmesi
}

\author{
Evaluation of work related stress and job satisfaction levels of surgical and internal \\ medicine nurses
}

\author{
Sibel Nargiz Koşucu1, Sonay Baltacı Göktaş², Tülin Yıldız \\ ${ }^{1}$ Başkent Üniversitesi İstanbul Hastanesi, İstanbul, Turkey \\ ${ }^{2}$ Medipol Üniversitesi Sağlık Bilimleri Fakültesi, Hemşirelik Bölümü, İstanbul, Turkey \\ ${ }^{3}$ Namık Kemal Üniversitesi, Sağlık Yüksek Okulu, Tekirdağ, Turkey
}

\begin{abstract}
Purpose: This study aims to compare the work related stress levels and job satisfaction levels of surgical nurses with internal medicine nurses.

Material and Methods: This declarative research has been perofmed with a sample of 110 nurses who work in the surgical and internal medicine units of a university hospital. Data has been collected by performing a survey that has been prepared according to the demographic and occupational status of participants. Additionally, measurements of work stress levels and job satisfaction have been used to collect data.

Results: Average scores for work related stress, inner satisfaction, outer satisfaction and general satisfaction of participants were $40.97 \pm 9.02,40.50 \pm 7.82,25.03 \pm 5.71$ and $65.53 \pm 13.20$ respectively. Surgical nurses had less work related stress levels than internal medicine nurses $(37.10 \mathrm{vs}$ 45.28). Also, surgical nurses had higher levels of inner satisfaction, outer satisfaction and general satisfaction. A significant association was found between the unit and the work conditions. $45.7 \%$ of the participants who do not like their work environment were surgical nurses, whereas the remaining $54.3 \%$ were internal medicine nurses.

Conclusion: This study revealed that the participating nurses have high work related stress and low job satisfaction in general. On average, surgical nurses had less work related stress and higher inner satisfaction than internal medicine nurses. The majority of the nurses who do not like their work environment were internal medicine nurses.
\end{abstract}

Key words: Work related stress, job satisfaction, nurse.
Öz

Amaç: Çalışma cerrahi ve dahiliye servislerinde çalışan hemşirelerin ișe bağlı gerginlik ve iş doyumu düzeylerinin değerlendirilmesi amacı ile yapıldı.

Gereç ve Yöntem: Tanımlayıcı olarak gerçekleștirilen çalışmanın örneklemini bir üniversite hastanesinin cerrahi ve dahiliye kliniklerinde çalıșan 110 hemșire oluşturdu. Çalışmanın verileri araştırmacılar tarafından ilgili literatüre dayalı olarak geliștirilen katılımcıların demografik ve mesleki bilgilerine yönelik anket formu, ișe bağlı gerginlik ölçeği ve iş doyum ölçeği kullanılarak toplandı.

Bulgular: Çalışanların "işe bağlı gerginlik" ortalaması

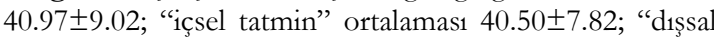
tatmin" ortalamasi $25.03 \pm 5.71$; "genel tatmin" ortalamas 65.53 \pm 13.20 idi. Cerrahi servislerde çalışan hemşirelerin işe bağlı gerginlik puanları (37.10), dahilive servislerde çalışanların işe bağlı gerginlik puanlarından (45.28) düşük bulundu. Cerrahi servis hemșirelerinin içsel tatmin, dıșsal tatmin ve genel tatmin puanlarının dahiliye hemşirelerinin puanlarından yüksek olduğu saptandı. Bölüm ile çalıșma koşulları arasında anlamlı bir ilişki bulundu. Çalışma koşullarını olumsuz değerlendirenlerin \%45.7'sinin cerrahi, $\% 54.3$ 'ünün dahiliye servislerindeki hemşirelerin olduğu belirlendi.

Sonuç: Hemşirelerin iş gerginliklerinin yüksek, is doyumlarının düşük olduğu bulundu. Cerrahi servislerde çalışan hemşirelerin dahiliye servislerde çalışan hemşirelere göre iş gerginlikleri daha düşük ve iç doyumları daha yüksek olduğu belirlenmiștir. Çalıșma koşullarını olumsuz değerlendiren hemşirelerin çoğunun dahiliye servislerinde çalışan hemşireler olduğu görüldü.

Anahtar kelimeler: İşe bağlı gerginlik, İş doyumu, hemşire. 


\section{GİRİ̧̧}

Bireyin çevredeki stresörlere karşıllk verdiği psikolojik tepkiler olarak tanımlanan işe bağl1 gerginlik yüksek iş talebi, düşük düzeyde kontrol ve sosyal desteğin düşük düzeyde olduğu iş koşullarında ortaya çımaktadır ${ }^{1,2}$. İşe bağlı gerginlik bireyi çalışma yaşamında mutsuzluğa, duygusal açıdan tükenmeye ve tatminsizliğe yöneltmektedir. Gerginlik arttıkça kişisel başarı, duygusal tükenme, duyarsızlaşma ve genel tükenmişlik de artmaktadır. Bunun sonucunda işe bağlı gerginliğin bireylerin iş doyumunu ve tükenmişlik düzeylerini etkileyen önemli bir faktör olduğu bilinmektedir. Bireyin işe bağlı gerginliği sadece iş yaşamıyla sınırlı kalmamakta, iş yaşamının devamı niteliği taşıyan genel yaşam tatminini de olumsuz etkileyebilmektedir. İş doyumu işi sevme, işe bağll1ık, işe kendisini verme gibi iş görenlerin işlerinden duydukları hoşnutluk olarak tanımlayabiliriz ${ }^{1,3-9}$.

İşe bağlı gerginlik insanlarla yoğun ve süreğen ilişkide olan mesleklerde görülmektedir. Sağlik bakım alanı, yoğun iş yükü, ağır ve ölümcül hastalara bakım verme, gerektiğinde hasta ve yakınlarına duygusal destek verme gibi nedenlerle, diğer iş alanlarından daha fazla iş stresinin yaşandığı bir ortam olarak değerlendirilmektedir. Sağlık çalışanları ile yapılan çalışmalarda iş ortamındaki stresörlerin sağlık çalışanlarının beden ve ruh sağlığını ve iş doyumunu olumsuz etkilediği saptanmıştır ${ }^{10-12}$.

İş stresinin, düşük otonomiye karşın, fiziksel ve psikolojik taleplerin fazla olduğu mesleklerde daha s1k görüldüğü bilinmekte ve hemşireliğin de bu meslek gruplarından biri olduğu kabul edilmektedir ${ }^{13}$.

İşle ilgili karşılaştıkları taleplerin fazlalığına karşılık, işlerini yaparken sahip oldukları otonominin azlığı, hemşirelerde mesleki stres ve tükenmişliğe katkıda bulunan önemli sorunlar olup, tükenmişlik ve stres arttıkça, işle ilgili doyumun ve çalışılan birimin etkinliğine inanışın azaldığ1 gösterilmiştir ${ }^{14}$. Hemşirelerin iş stresinin yüksek olması, tükenmişliğin yanı sıra, iş doyumlarında azalma, sundukları hizmetin kalitesinde düşme ve işten ayrilma eğilimlerinde artma gibi sorunlara da yol açmaktadır. İş stresi arttıkça iş doyumunun, üretkenliğin ve kuruma bağl1lığın azaldığı; iş stresinin tükenmişlik sendromu oluşumunda rol oynadığ ve hemşirelerde hastalık ve işe devamsızlıkta önemli bir etken olduğu saptanmıştır 15-17. Hemşirelerin çalıştıkları üniteler ve çalışma koşulları işe bağlı stres, tükenmişlik ve iş doyum düzeylerini etkileyen faktörler arasında yer almaktadır. Birçok araştırma hemşirelerin işe bağlı stres düzeylerinin çalıştıkları birimlere göre farklılık gösterdiğini belirtmektedirr ${ }^{18-}$ 20.

Sonuç olarak; sağlık sisteminin önemli bir parçası olan hemşirelerin işe bağlı gerginlik yaratan faktörlerin bilinmesi ile alınacak önlemler belirlenebilir. İşe bağlı gerginlik etkilerinin önlenerek iş doyumunun ve veriminin arttırılması, çalışan sağlığının korunması ve olumlu sonuçların hasta bakım kalitesine yansıtılması sağlanabilir.

$\mathrm{Bu}$ araştırmada, cerrahi ve dahiliye servislerinde çalışan hemşirelerinin iş gerginliği ve doyum düzeylerinin incelenmesi ve işle bağlantılı stres, tükenmişlik ve doyum arasındaki ilişkilerin incelenmesiyle bilimsel literatüre özgün ve önemli bir katkıda bulunmak hedeflenmiştir.

\section{GEREÇ VE YÖNTEM}

Araştırma Başkent Üniversitesi İstanbul Sağllk Uygulamam ve Araştırma Merkezi'nin cerrahi ve dahiliye birimlerinde çalışan hemşirelerin işe bağlı gerginlik ve iş doyumu düzeylerinin belirlenmesi amacıyla tanımlayıcı olarak planlandı. Araştırmanın evrenini hastanenin dahiliye ve cerrahi birimlerinde çalışan 121 hemşire, örneklemini ise izinli raporlu olmayan ve gönüllülük esasına göre araştırmaya katılmayı kabul eden 110 hemşire oluşturdu. Çalışmada veri toplama aracı olarak, araştırmacılar tarafindan oluşturulan katılımcıların demografik ve mesleki bilgilerine yönelik 20 adet çoktan seçmeli soru içeren anket formu, işe bağlı gerginlik ölçeği ve iş doyum ölçeği kullanıldı. Katılımcılardan aydınlatılmış onam alındıktan veri toplama araçları verilmiş ve aynı gün tekrar toplanmıştır.

\section{Kullanılan Ölçekler}

\section{İşe Bağlı Gerginlik Ölçeği}

Araştırmaya katılanların işe bağlı gerginlik düzeylerini belirlemek için Revicki ve arkadaşları tarafindan 1991 yılında geliştirilmiş olan ve Türkçe formunun geçerlilik ve güvenirliği Aslan ve arkadaşları tarafindan yapılan işe bağlı gerginlik ölçeği kullanıldı9 . Ölçek 18 sorudan oluşan 4lü likert tipi bir öz bildirim ölçeğidir. Ölçekte yer alan ifadeler için 1= Bana hiç uygun değil, 2=Kısmen bana uygun, 3=Bana uygun, 4=Büyük ölçüde bana 
uygun, $5=$ Tamamiyla bana uygun șeklinde puanlama istenmiştir. Ölçekte yer alan 2, 4, 8, 9, ve 11. ifadeler ters yönde puanlanmaktadır. Alınabilecek en düşük puan 18 , en yüksek puan 72 'dir. Aslan ve arkadaşları tarafindan güvenirlik katsayısı 0.85 ile 0.90 arasinda bulunmuştur ${ }^{21}$.

\section{İş Doyum Ölçeği}

Weiss ve arkadaşları (1967) tarafindan iş doyumunu ölçmek amacıyla geliştirilmiş olup 20 sorudan oluşan 5'li likert tipi bir ölçektir. Ölçeğinin İngilizce'den Türkçe'ye çevirisi Deniz ve Güliz Gökçora tarafından yapılmıştır. Daha sonra çeviri yeniden yapılarak geçerliğ̣i kanıtlanmış ve Boğaziçi Üniversitesi'nden Boycan tarafindan çalışanlar üzerinde denemeleri yapılmıştır. Ölçekten alınabilecek en yüksek puan 100 , en düşük puan 20 olup, orta noktaya düşen 60 ise nötr doyumu ifade etmektedir. Minnesota İş Doyum toplam puanlarına göre şu sinıflandırma yapılmıştır: 0 - 49 puan düşük, 50 - 69 puan - orta, 70 - 89 puan - yüksek, $90-100$ puan - çok yüksek olarak değerlendirildi ${ }^{22}$. $\mathrm{Bu}$ çalışma Başkent Üniversitesi Tip ve Sağlık

Tablo 1. Sosyo-demografik özellikler

\begin{tabular}{|c|c|c|c|}
\hline & & $\mathbf{n}$ & $\%$ \\
\hline \multirow[t]{4}{*}{ Yaş } & $19 \mathrm{Ve}$ Alt1 & 17 & 15.5 \\
\hline & $20-24$ & 28 & 25.5 \\
\hline & $25-29$ & 33 & 30.0 \\
\hline & 30 ve üstü & 32 & 29.1 \\
\hline \multirow[t]{2}{*}{ Cinsiyet } & Kadın & 80 & 72.7 \\
\hline & Erkek & 30 & 27.3 \\
\hline \multirow[t]{2}{*}{ Bölüm } & Cerrahi & 58 & 52.7 \\
\hline & Dahiliye & 52 & 47.3 \\
\hline \multirow[t]{2}{*}{ Medeni Durum } & Bekar & 82 & 74.5 \\
\hline & Evli & 28 & 25.5 \\
\hline \multirow[t]{2}{*}{ Eğitim Durumu } & Lise & 44 & 40.0 \\
\hline & Üniversite & 66 & 60.0 \\
\hline \multirow{2}{*}{ Çocuk } & Var & 20 & 18.2 \\
\hline & Yok & 90 & 81.8 \\
\hline \multirow[t]{4}{*}{ Bölümde Çalışma Süresi } & 1 Ylldan $\mathrm{Az}_{z}$ & 23 & 20.9 \\
\hline & 1-3 Y1l Aras1 & 41 & 37.3 \\
\hline & $4-6 Y_{1}$ & 31 & 28.2 \\
\hline & 7 Yll ve Üstü & 15 & 13.6 \\
\hline \multirow[t]{4}{*}{ Toplam Çalışma Süresi } & 1 Ylldan Az & 16 & 14.5 \\
\hline & 1-3 Y1l Aras1 & 33 & 30 \\
\hline & $4-6 Y_{11}$ & 31 & 28.2 \\
\hline & 7 Yil ve Üstü & 30 & 27.3 \\
\hline \multirow{2}{*}{$\begin{array}{l}\text { Haftalık Ortalama Çalışma } \\
\text { Süresi }\end{array}$} & 48 saat ve alt1 & 68 & 61.8 \\
\hline & 48 saat üstü & 42 & 38.2 \\
\hline \multirow{2}{*}{$\begin{array}{l}\text { Günlük Bakılan Ortalama } \\
\text { Hasta Sayısı }\end{array}$} & 6 ve daha az hasta & 45 & 40.9 \\
\hline & 7-9 Hasta & 52 & 47.3 \\
\hline
\end{tabular}

Bilimleri Araştırma Kurulu tarafindan onaylandı (Proje no: KA16/22).

\section{İstatistiksel analiz}

Verilerin değerlendirilmesinde SPSS 21.0 paket programı kullanilarak bilgisayarda yapildı. Katılımciların bireysel ve mesleki tanımlayıc1 özellikleri yüzdelik değerler, bu özelliklerle işe bağlı gerginlik ölçeği ve iş doyum ölçeği arasındaki ilişkinin incelenmesinde korelasyon analizi, Kruskal Wallis ve Mann-Whitney U testleri kullanılmıştır.

\section{BULGULAR}

Araştırmaya alınan hemşirelerin \%30'unun 25-29 yaş aralığında, \%72.7'sinin kadın, \%54.5'inin lisans mezunu, \%74.5'inin bekar ve \%81.8'inin çocuğunun olmadığ1 belirlendi. Örnekleme alınan hemşirelerin \%52.7'si cerrahi, \%47.3'ü dahiliye bölümünde çalıştı̆̆1, \%30'nunun toplam çalışma süresinin 1-3 y1l, \%37.3'ünün bölümde çalışma yılının 1-3 yıl olduğu saptandı. Çalışanların \%61.8 inin haftalık çalışma süresi 48 saat üstü olduğu ve \%47.3’ünün günlük ortalama 7-9 hasta baktığı belirlendi (Tablo 1). 
Çalışanların “işe bağlı gerginlik" ortalaması $40.97 \pm$ 9.02, "içsel tatmin" ortalaması $40.50 \pm 7.82$, "dişsal tatmin" ortalamas1 $25.03 \pm 5.71$, "genel tatmin" ortalamas1 $65.53 \pm 13.20$ olarak saptand1 (Tablo 2).

İşe bağlı gerginlik ile tatmin düzeyi arasındaki ilişkiyi belirlemek üzere yapilan korelasyon analizi sonucunda, puanlar arasinda negatif yönde anlamlı ilişki bulundu. Buna göre işe bağlı gerginlik arttı̆̆ında, içsel tatmin $(\mathrm{r}=-0.663 ; \mathrm{p}=0.000<0.05)$, dişsal tatmin $(\mathrm{r}=-0.694 ; \mathrm{p}=0.000<0.05)$ ve genel tatmin azalmaktadır $(\mathrm{r}=-0.693 ; \mathrm{p}=0.000<0.05)$.

Katılımcıların çalıştıkları bölümlere göre işe bağlı gerginlik puan ortalamaları açısından aralarında anlamlı fark olduğu saptandı (Mann Whitney $\mathrm{U}=748.500 ; \mathrm{p}=0.000$ ). Cerrahi kliniklerde çalışan hemşirelerin işe bağlı gerginlik puan ortalamaları (37.10), dahiliye kliniklerde çalışanların işe bağlı gerginlik puanlarından (45.28) düşük olarak belirlendi (Tablo 4).

Katılımcıların çalıştıkları bölümlere göre içsel (Mann Whitney $U=1$ 099.500; $p=0.014$ ), dişsal (Mann Whitney $U=1$ 045.500; $\mathrm{p}=0.005)$ ve genel tatmin (Mann Whitney $\mathrm{U}=1$ 061.500; $\mathrm{p}=0.007$ ) puan ortalamaları açısından aralarında anlamlı fark olduğu saptand. Cerrahi kliniklerde çalışan hemşirelerin içsel (42.17), dişsal (26.48) ve genel tatmin puan ortalamaları (68.65) dahiliye kliniklerde çalışan hemşirelerden daha yüksek olduğu belirlendi (sirasiyla 38.63, 23.42, 62.05) (Tablo 4).

Bölüm ile çalışma koşulları arasında anlamlı ilişki olup, $\left(\mathrm{X}^{2}=3.798 ; \mathrm{p}=0.040<0.05\right)$ çalışma koşullarını olumsuz değerlendirenlerin \% 45.7'sinin cerrahi, \%54.3'ünün dahiliye hemşireleri olduğu görüldü. Çalışma koşulları değerlendirildiğinde; yetersiz personel, yetersiz tıbbi malzeme, ücret yetersizliği, akademik ilerleyememe, kendini geliştirememe, sosyal imkan kısıtlılığ1 ve yemek imkanı $\left(\mathrm{X}^{2}=0.465\right.$; $\mathrm{p}=0.459>0.05)$ konularında cerrahi ve dahiliye hemşireleri arasında anlamlı farklılık görülmez iken fazla iş gücü açısından bölümler arası anlamlı farklilik saptandi.

Cerrahi hemşirelerinin \%10.3'ü, dahiliye hemşirelerinin \%30.8'i fazla iş gücünü olumsuz çalışma koşulu olarak değerlendirdiği belirlendi. Bakım yükü fazla olan hasta takibi açısından cerrahi ve dahiliye bölümü arasında anlamlı fark bulundu $\left(X^{2}=5.142 ; \quad p=0.024<0.05\right)$. Cerrahi servis hemşirelerinin \%1.9'unun, dahiliye hemșirelerinin \%13.8'i nin bakım yükü fazla olan hasta takibini olumsuz çalışma koşulu olarak değerlendirdiği saptand1 (Tablo 5).

\section{TARTIŞMA}

$\mathrm{Bu}$ çalışmada hemşirelerin "işe bağlı gerginlik" ortalamasının (40.97) ölçeğin puan aralığının 17-85 olması nedeniyle orta düzeyde olduğu söylenebilir. Yapılan bir çalışmada hemşirelerin işe bağlı gerginlik düzeyi 39.20 olarak bildirilmektedir ${ }^{23}$. Çalışmada elde ettiğimiz işe bağlı gerginlik ortalamasının bu çalışma ile benzerlik gösterdiği belirlendi (Tablo 2). Sağlık bakım alanları birçok iş alanına göre daha fazla iş stresinin yaşandığı alanlardır ${ }^{10-12}$.

Tablo 2. İşe Bağlı Gerginlik ve Tatmin ortalamaları

\begin{tabular}{|l|c|c|c|c|}
\hline & Ort & Ss & Min. & Max. \\
\hline İşe Bağlı Gerginlik & 40.97 & 9.02 & 29 & 59 \\
\hline İçsel Tatmin & 40.5 & 7.82 & 24 & 59 \\
\hline Dişsal Tatmin & 25.03 & 5.71 & 11 & 39 \\
\hline Genel Tatmin & 65.53 & 13.2 & 39 & 98 \\
\hline
\end{tabular}

Katılımcıların genel tatmin puanlarının orta düzeyde olduğu belirlendi. Nurluöz (2012) ve arkadaşları çalışmalarında hemşirelerin iş doyumunun düşük olduğunu $^{24}$, Balc1 (2010) ise hemşirelerin iş doyumu düzeyinin 47.89 olduğunu belirtmiştir ${ }^{25}$. Bu çalışmada elde edilen genel tatmin düzeyi orta düzeyde olup, diğer çalıșmalara göre daha yüksek bulunmuştur (Tablo 3). Üniversite Hastanelerinde çalışan hemşirelerin iş tatmin düzeyinin özellikle devlet hastanelerinde, kısmen de özel hastanelerde çalıșan hemșirelere göre daha olumlu çıtığı belirtilmektedir ${ }^{24}$. $\mathrm{Bu}$ çalışmanın üniversite hastanesinde, diğer çalışmaların çoğunun devlet hastanelerinde yapılmış olmasının iş tatmininin yüksek çımasında etkisi olabileceği düşünülmektedir. 
Tablo 3. İşe Bağlı Gerginlik ve Tatmin ilişkisine ilişkin korelasyon analizi

\begin{tabular}{|l|c|}
\hline İş Tatmini & İşe bağlı gerginlik \\
\hline İçsel tatmin & $\mathrm{r}=-0.663, \mathrm{p}<0.0001$ \\
\hline Dişsal tatmin & $\mathrm{r}=-0.694, \mathrm{p}<0.0001$ \\
\hline Genel tatmin & $\mathrm{r}=-0.693, \mathrm{p}<0.0001$ \\
\hline
\end{tabular}

r: korelasyon katsayis1

Tablo 4. İşe Bağlı Gerginlik ve Tatmin düzeylerinin bölüm değişkenine göre dağılımı

\begin{tabular}{|c|c|c|c|c|c|c|}
\hline & & $\mathbf{N}$ & Ort & Ss & MW & $\mathrm{p}$ \\
\hline \multirow[t]{2}{*}{ İşe Bağlı Gerginlik } & Cerrahi & 58 & 37.103 & 6.515 & \multirow[t]{2}{*}{748.500} & \multirow[t]{2}{*}{0.000} \\
\hline & Dahiliye & 52 & 45.289 & 9.514 & & \\
\hline \multirow[t]{2}{*}{ İçsel Tatmin } & Cerrahi & 58 & 42.172 & 7.495 & \multirow[t]{2}{*}{1099.500} & \multirow[t]{2}{*}{0.014} \\
\hline & Dahiliye & 52 & 38.635 & 7.837 & & \\
\hline \multirow[t]{2}{*}{ Dişsal Tatmin } & Cerrahi & 58 & 26.483 & 5.452 & \multirow[t]{2}{*}{1045.500} & \multirow[t]{2}{*}{0.005} \\
\hline & Dahiliye & 52 & 23.423 & 5.609 & & \\
\hline \multirow{2}{*}{ Genel Tatmin } & Cerrahi & 58 & 68.655 & 12.537 & \multirow[t]{2}{*}{1061.500} & \multirow[t]{2}{*}{0.007} \\
\hline & Dahiliye & 52 & 62.058 & 13.181 & & \\
\hline
\end{tabular}

Ss: Standart sapma MW: Mann Whitney U

İşe bağlı gerginlik ile içsel tatmin arasındaki ilişkiyi belirlemek üzere yapilan korelasyon analizi sonucunda, puanlar arasinda negatif yönde anlamlı ilişki bulundu. Buna göre işe bağlı gerginlik arttıkça içsel tatmin $(r=-0.663 ; \mathrm{p}=0.000)$ dişsal tatmin $(\mathrm{r}=$ $0.694 ; \mathrm{p}=0.000)$ ve genel tatmin azalmaktadır $(\mathrm{r}=-$ $0.693 ; \mathrm{p}=0.000$ ) (Tablo 4). Bu sonuç, işe bağlı gerginlik ve iş tatmini arasındaki negatif ilişkiyi doğrulayan pek çok araştırma sonuçlarıyla benzerlik göstermektedir. Yüksek düzeyde işe bağlı gerginliğin düşük düzeyde iş tatmini ile ilişkilendirildiği bildirilmektedir ${ }^{1,18,25,26}$.

Cerrahi kliniklerde çalışan hemşirelerin işe bağlı gerginlik puanlarının dahiliye kliniklerde çalışanların puanlarından düşük olduğu saptandı (Tablo 4). Dahiliye servislerinde çalışan hemşirelerin stres ve depresyon düzeylerinin diğer birimlerden yüksek olduğu bildirilmektedir ${ }^{18}$. Benzer şekilde başka çalışmalarda da onkoloji hemşirelerinin tükenmişlik düzeylerinin cerrahi hemşirelerden yüksek olduğu görüldü26,27. Diğer çalışmalarda olduğu gibi bu çalıșmada dahiliye hemșirelerinin ișe bağlı gerginlik puanının cerrahi hemşirelerinden yüksek olduğu saptandi. $\mathrm{Bu}$ sonucun dahiliye hemşirelerinin çoğunun çalışma koşullarını olumsuz ve fazla iş gücü gerektirdiğini belirtmelerinden kaynaklandığ1 düşünülmektedir.

İşe bağlı gerginlik düzeyi düşük olan cerrahi hemşirelerinin içsel tatmin, dişsal tatmin ve genel tatmin puanları, dahiliye kliniklerde çalışanların puanlarından yüksek bulundu (Tablo 4). Çalışmada elde edilen bulguların tersine bir çalışmada dahiliye biriminde çalışan hemşirelerin iş doyumu düzeyinin diğer bölümlerde çalışan hemşirelerden anlamlı şekilde yüksek olduğu belirtilmiştir ${ }^{24}$. Başka bir çalışmada ise hemşirelerin iş doyumu ortalamalarının çalıştığı bölüm değişkenine göre anlamlı bir farklılık göstermediğini belirtmiştir ${ }^{25}$. Bu çalışmada, işe bağlı gerginliğin yüksek olduğu dahiliye hemșirelerinin iş tatmin düzeylerinin de daha az olduğu saptandi. Bunun nedeninin dahiliye hemşirelerinin çoğunun (\%54.3) çalıșma koșullarını olumsuz olarak değerlendirmesi olduğu görülmektedir. Ayrıca dahiliye hemşirelerinin çoğu (\%30.8) fazla iş gücü ve bakım yükü fazla olan kronik hasta bakımı konularını olumsuz çalışma koşulu olarak belirtmişlerdir (Tablo 5). Çalışma koşulları kişilerin stress düzeyini ve iş doyum düzeyini doğrudan etkilemektedir. Bu nedenle dahiliye hemșirelerinin çalışma koşullarını olumsuz bulmasının iş tatmini ve işe bağlı gerginlik düzeyini etkilediğini desteklemektedir.

olmasındaki temel faktörlerin fazla iş yükü ve ölümle ilgili duygusal sorunlar olduğuna dikkat çekmiştirr ${ }^{18}$. Dahiliye hemşirelerinin, ameliyathane ve acil hemşirelerinden daha yüksek stres düzeyine sahip olduğu, bunun nedeninin hemşirelerin uzun süre boyunca aynı hastalara bakım vermeleri olduğu belirtilmektedir ${ }^{18}$. Bașka bir çalıșmada hemșirelerde ölümcül ya da çok kritik hasta bakımından kaynaklanan ağır iş yükü ve sorumluluğun strese yol açtığ bildirilmiştir ${ }^{28}$. Bu çalışmada da benzer şekilde dahiliye hemşirelerinin çoğunun "fazla iş gücü” ve 
"bakım yükü fazla olan ve kronik hastalığ1 olan hasta takibini” olumsuz çalışma koşulu olarak belirttiği saptandı. Dahiliye hemşirelerinin işe bağlı gerginlik düzeyinin yüksek ve iş tatminin düşük olması, bakım verdikleri hastaların kronik ve terminal dönem hastalar olmasından kaynaklandığ1 düşünülebilir. Ayrıca cerrahi hemşirelerinin bakım verdiği hastaların kısa süreli yatan ve kronik olmayan hastalar olması bu sonucun nedeni olduğunu düşündürmektedir.

Tablo 5. Bölümlere göre çalışma koşullarının değerlendirilmesi

\begin{tabular}{|c|c|c|c|c|c|}
\hline \multirow[t]{2}{*}{ Çalışma Koşulları } & \multicolumn{2}{|c|}{ Cerrahi } & \multicolumn{2}{|c|}{ Dahiliye } & \multirow[t]{2}{*}{$\mathrm{p}$} \\
\hline & $\mathrm{n}$ & $\%$ & $\mathrm{n}$ & $\%$ & \\
\hline Olumlu & 26 & $\% 65.0$ & 14 & $\% 35.0$ & \multirow[t]{2}{*}{$\mathrm{X} 2=3.798 \mathrm{p}=0.040$} \\
\hline Olumsuz & 32 & $\% 45.7$ & 38 & $\% 54.3$ & \\
\hline Yetersiz Personel & 36 & $\% 62.1$ & 37 & $\% 71.2$ & $\mathrm{X} 2=1.014 \mathrm{p}=0.211$ \\
\hline Fazla İş Gücü & 6 & $\% 10.3$ & 16 & $\% 30.8$ & $\mathrm{X} 2=7.149 \mathrm{p}=0.007$ \\
\hline Yetersiz Tibbi Malzeme & 26 & $\% 44.8$ & 27 & $\% 51.9$ & $\mathrm{X} 2=0.553 \mathrm{p}=0.290$ \\
\hline Ücret Yetersizliği & 28 & $\% 48.3$ & 30 & $\% 57.7$ & $\mathrm{X} 2=0.975 \mathrm{p}=0.213$ \\
\hline Akademik İlerleyememe & 2 & $\% 3.4$ & 3 & $\% 5.8$ & $\mathrm{X} 2=0.340 \mathrm{p}=0.448$ \\
\hline Kendini Geliştirememe & 2 & $\% 3.4$ & 0 & $\% 0.0$ & $\mathrm{X} 2=1.826 \mathrm{p}=0.276$ \\
\hline Sosyal İmkan Kısıtlılı̆g & 18 & $\% 31.0$ & 25 & $\% 48.1$ & $\mathrm{X} 2=3.345 \mathrm{p}=0.051$ \\
\hline Bakım yükü fazla olan ve kronik hasta takibi & 1 & $\% 1.9$ & 8 & $\% 13.8$ & $\mathrm{X} 2=5.142 \mathrm{p}=0.024$ \\
\hline Yemek & 1 & $\% 1.7$ & 2 & $\% 3.8$ & $\mathrm{X} 2=0.465 \mathrm{p}=0.459$ \\
\hline
\end{tabular}

Chiang ve Chang'in belirttiğine göre Lambert ve arkadaşları hemşirelerdeki iş stresinin yüksek Yaşlı hastalara bakım veren hemșirelere yapılan hasta bakım eğitiminin, hemşirelerin iş yüküne bağlı stres düzeyini azalttığ1 belirtilmiştir ${ }^{29}$. Ayrıca cerrahi hemşirelerine terminal dönem kanser hastalarının bakımı sürecinde iletişim ve karar sürecine yönelik verilen eğitimin işe bağlı stres, iş yükü stresi ve hayal kırıklığ1 duygusunu azalttığ1 bildirilmiştir ${ }^{30}$. Bu çalışmalarda hemşirelere özel hasta gruplarına yönelik verilen bakım eğitiminin iş stresini azalttığ1 bildirilmektedir.

Yetersiz personel ve trbbi malzeme, ücret yetersizliği, akademik ilerleyememe, kendini geliştirememe, sosyal imkan k1sıtlliı̆̆ ve yemek imkanı gibi çalışma koşullarını değerlendiren cerrahi ve dahiliye hemşireleri arasında anlamlı farklılık görülmemesi tüm hemşirelerin bu koşullar hakkında paralel düşüncelerde olduğunu göstermektedir. Bu koşulların bölüme özgü olmadığı ve çalışanların hepsini aynı şekilde etkilemesi nedeniyle olduğu söylenebilir.

$\mathrm{Bu}$ çalışmanın kısıtlılıkları çalışmanın ulaşılabilirliği ve tamamlanabilmesi için yalnızca bir üniversite hastanesinde yapılmış olmasıdır.

Sonuç olarak hemşirelerin işe bağlı gerginlik düzeyleri arttıkça, iş tatmini düzeylerinde azalma olduğu, cerrahi kliniklerde çalışan hemşirelerin işe bağlı gerginlik puan ortalamalarının dahiliye kliniklerde çalışanların puan ortalamasından düşük olduğu, içsel, dışsal ve genel tatmin puanlarının yüksek olduğu belirlendi.

$\mathrm{Bu}$ sonuçlar doğrultusunda; iş yükü fazla olan, bağımlı, kronik ve/veya terminal dönem hastaların yattığ birimlerdeki hemşirelere, stresle baş etme yöntemleri konusunda hizmet içi eğitimler planlanmalıdır. Ayrıca bu bölümlerde hasta sayısı ve bakım yüküne uygun hemşire insan gücü planlaması oldukça önemlidir. Hemşirelerin iş doyumunu arttırmaya yönelik girişimlerde bulunulmalı iş gerginliği yüksek, iş tatmini düşük olan birimlere motivasyonu arttırmaya yönelik planlamalar yapilmalidir.

\section{KAYNAKLAR}

1. Yürür S, Keser A. İșe bağlı gerginlik ile iş tatmini ilișikisinde duygusal tükenmenin aracı rolü. Ankara Üniversitesi SBF Derg. 2011;65:165-94.

2. Croon D, Einar M, Judith K, Sluiter, Ronald WB, Blonk J et al. Stressful work, psychological job strain, and turnover: a 2- year prospective cohort study of truck drivers. J Appl Psychol. 2004;89:442-54.

3. Bourbonnais RM. Job strain and sickness absence among nurses in the province of quabec. Am J Ind Med. 2001;39:194-202.

4. Hasan G, Oktay E, Gökçe H. İş tatmini, stres, örgütsel bağll11k, ișten ayrılma niyeti ve performans arasındaki ilişkiler: sağlık sektöründe bir uygulama. Akademik Bakıș. 2008;15:1-11.

5. Tennant C. Work-related stress and depressive disorders. J Psychosom Res. 2001;51:697-704. 
6. Arı GS, Bal EÇ. Tükenmişlik kavramı: birey ve örgütler açısından önemi. Yönetim ve Ekonomi. 2008;15:131-48.

7. Sünter AT, Canbaz S, Dabak Ş, Öz H, Pekşen Y. Pratisyen hekimlerde tükenmişlik, işe bağlı gerginlik ve iş doyumu düzeyleri. Genel Tip Dergisi. 2006;16:9-14.

8. Canbaz S, Sünter T, Dabak Ş, Öz H, Peşken Y. Hemşirelerde tükenmişlik sendromu iș doyumu ve işe bağlı gerginlik. Hemşire Forum. 2001;4:31-4.

9. Aslan $\mathrm{SH}$, Alparslan $\mathrm{ZN}$, Aslan RO. İșe bağlı gerginlik ölçeğinin sağlık alanında çalışanlarda geçerlik ve güvenirliği. Dusunen Adam. 1998;11:4-8.

10. Clegg A. Occupational stress in nursing: a review of the literature. J Nurs Manag. 2001;9:101-6.

11. Bryant C, Fairbrother G, Fenton P. The relative influence of personal and workplace descriptors on stress. Br J Nurs. 2000;9:876-80.

12. Lacovides A, Fountoulakis KN, Kaprinis S, Kaprinis G. The relationship between job stress, burnout and clinical depression. J Affect Disord. 2002:75:209-11.

13. Sever Dinç A. Hemșirelerin iș stresi ile bașa çıma yolları ve bunların sonuçlarının araştırılması. (Doktora tezi). İstanbul, İstanbul Üniversitesi, 1997.

14. Stordeur S, Vadenberghe C, D'hoore W. Predictors of nurses' professional burnout: a study in a university hospital. Rech Soins Infirm. 1999;59:5767.

15. Altay B, Gönener D, Demirkıran C. Bir üniversite hastanesinde çalışan Hemşirelerin tükenmişlik düzeyleri ve aile desteğinin etkisi. Fırat Tıp Dergisi. 2010;15:10-6.

16. Çam O. Tükenmişlik. İzmir, Saray Kitabevi , 1995.

17. Tel H, Karadağ M, Tel H, Aydın Ş. Sağlık çalıșanlarının çalıșma ortamındaki stres yaşantıları ile baş etme durumlarının belirlenmesi. Hemşirelikte Araștırma Geliștirme Dergisi. 2003;5:13-24.

18. Chiang YM, Changa Y. Stress, depression, and intention to leave among nurses in different medical units: implications for healthcare management / nursing practice. Health Policy. 2012;108:149-57

19. Dewe PJ. Examination the nature of work stress: individual evaluation of stressful experiences and coping. Hum Relat. 1989;42:993-1013.

20. Cole FL, Slocumb EM, Mastey JM. A measure of critical care nurses' post-code stress. J Adv Nurs. 2001;34:281-8.

21. Aslan SH, Gürkan SB, Girginer, HU, Ünal M. İșe Bağlı Gerginlik Ölçeğinin bir hemşire örnekleminde geçerlik ve güvenirliği. 3P Dergisi. 1996;4:276-83.

22. Baycan FA. Farklı çalışan gruplarda iş doyumunun bazı yönlerinin analizi. (Bilim uzmanlığı tezi). İstanbul, Boğaziçi Üniversitesi, 1985.

23. Arrkan D, Karabulut N. Hemşirelerde işe bağlı gerginlik ve bunu etkileyen faktörlerin belirlenmesi. Atatürk Üniversitesi Hemşirelik Yüksekokulu Dergisi. 2004;7:20-6.

24. Nurluöz Ö, Akçıl U. Hemşirelerin iş güçlügünü oluşturan değişkenlerinin iș doyumu ile karșilaștırmalı analizi. Hacettepe Üniversitesi Eğitim Fakültesi Dergisi. 2012;2:77-86.

25. Balc1 E. Hemşirelerde iş tatmini faktörlerinin hastaneye olan bağlllıklarına etkisi. (Yüksek lisans tezi). İstanbul, Beykent Üniversitesi , 2010.

26. Yavuzyılmaz A, Topbaș M, Can E, Özgün Ș. Trabzon il merkezindeki sağlık ocakları çalışanlarında tükenmislik sendromu ile is doyum düzeyleri ve ilişkili faktörler. TAF Prev Med Bull. 2007;6:41-50.

27. Ksiazek I, Stefaniak TJ, Stadnyk M, Ksiazek, J. Burnout syndrome in surgical oncology and general surgery nurses: A cross-sectional study. Eur J Oncol Nurs. 2011;15:347-350

28. Aslan SH, Aslan RO, Kesepara C, Alparslan N, Ünal M. Kocaeli'nde bir grup sağlık çalışanında işe bağlı gerginlik, tükenme ve iş doyumu. Toplum ve Hekim. 1997;12:24-9.

29. Singh I, Morgan K, Bellud G, Verma A, Aithal S. Does nurses' education reduce their work-related stress in the care of older people? J Clin Gerontol \& Geriatr. 2015;6:34-7.

30. Udo C, Danielson E, Henoch I, Melin-Johansson C. Surgical nurses' work-related stress when caring for severely ill and dying patients in cancer after participating in an educational intervention on existential issues. Eur J Oncol Nurs. 2013;17:546-53. 